\title{
DEVELOPMENT OF CORN HYBRIDS (Zea mays) UNDER INOCULATION OF DIAZOTROPHIC BACTERIA AND NITROGEN FERTILIZATION
}

\author{
João Paulo Kruger Reznick ${ }^{* 1}$, Volnei Pauletti ${ }^{2}$, Daniel Malheiro do Nascimento ${ }^{1}$, Marcus Vinicius \\ Cremonesi $^{1}$
}

\author{
1Discente da Universidade Federal do Paraná - Campus Curitiba, Curitiba - PR \\ ${ }^{2}$ Docente da Universidade Federal do Paraná - Campus Curitiba, Curitiba - PR \\ Autor para correspondência: João Paulo Kruger Reznick, joao_paulokr@hotmail.com
}

\begin{abstract}
: the aim of this work was to evaluate the development of corn genotypes under the effect of inoculation with Azospirillum brasilense in association with nitrogen fertilization. The experimental design was completely randomized in a $(5 \times 2 \times 2)$ factorial design with three replicates. Five corn hybrids were used, combined with two nitrogen $(\mathrm{N})$ doses (without $\mathrm{N}$ and with $100 \mathrm{~kg} \mathrm{ha}^{-1} \mathrm{~N}$ ) and two levels of A.brasilense inoculation (without and with inoculation). Plant height and stem diameter at stadiums V8 and R1, leaf chlorophyll content at stadium R1 and dry mass at stadium R2 were evaluated. It was observed that variations in the evaluated parameters are due to the different genetic materials and mainly due to the application of N. Inoculation with A.brasilense was not effective for changing corn development.
\end{abstract}

KEY WORDS: Azospirillum brasilense, biological nitrogen fixation, genotypes

\section{DESENVOLVIMENTO DE HÍBRIDOS DE MILHO (Zeamays) SOB INOCULAÇÃO DE BACTÉRIAS DIAZOTRÓFICAS E ADUBAÇÃO NITROGENADA}

RESUMO: o objetivo deste trabalho foi avaliar o desenvolvimento de genótipos de milho sob efeito da inoculação com Azospirillum brasilense (AZ) em associação com adubação nitrogenada. 0 delineamento experimental utilizado foi o inteiramente casualizado em esquema fatorial $(5 \times 2 \times 2)$, com três repetições. Foram utilizados cinco híbridos de milho, combinados com duas doses de nitrogênio (N) (sem N e com $100 \mathrm{~kg} \mathrm{ha}^{-1}$ de N) e com dois níveis de inoculação com A.brasilense(sem e com inoculação). Avaliou-se a estatura de planta e o diâmetro de colmo nos estádios V8 e R1, o teor de clorofila na folha em estádio R1 e a massa seca da parte aérea no estádio R2. Observou-se que quando houve variação nos parâmetros avaliados, esta foi devido aos diferentes materiais genéticos e principalmente devido à aplicação de N. A inoculação com A.brasilense não foi eficiente em alterar 0 desenvolvimento do milho.

PALAVRAS-CHAVE: Azospirillum brasilense, fixação biológica de nitrogênio, genótipos

\section{INTRODUCTION}

Corn is the world's largest volume-produced cereal, exceeding one billion tonnes (FAO, 2013a), and Brazil is the third world's largest producer (FAO, 2013b). Brazilian corn production in the 2016/2017 harvest reached 92.8 million tonnes and average productivity of $5,300 \mathrm{~kg} \mathrm{ha}^{-1}$, representing $40 \%$ of total grain production (Conab, 2017). However, the average productivity is relatively low, since there are regions in the country with corn crops under no-tillage system, with average yields of 9,000 to $10,000 \mathrm{~kg} \mathrm{ha}^{-1}$ (Fontoura, 2005; Nogara Neto et al., 2011).
Nitrogen is one of the nutrients with the greatest effects to increase corn production, being fundamental for plant metabolism, by participating in the synthesis of proteins and chlorophylls (Hawkesford et al., 2012). Adequate nitrogen supply is essential to achieve high yields, although it is the nutrient most deficient in practically all soil classes, and $\mathrm{NO}_{3}^{-}$and $\mathrm{NH}_{4}^{+}$are the inorganic forms absorbed by plants (Okumura et al., 2011). The availability of this nutrient through nitrogen fertilizers represents one of the highest costs in the production of non-leguminous crops, as corn, wheat and rice crops consume approximately $60 \%$ of the total 
world's nitrogen as fertilizer (Ladha et al., 2005) and less than $50 \%$ applied in this form is used by plants (Halvorson et al., 2002).

Diazotrophic bacteria can be an alternative to reduce the use of nitrogen fertilizers in cereals (Hungria et al., 2010) and consequently reduce production costs. Among these bacteria, the most important are those of the genus Azospirillum in association with grasses (Radwan et al., 2004), which fix atmospheric $\mathrm{N}_{2}$ in association with several non-leguminous species (Döbereiner and Pedrosa, 1987) and produce various growth hormones (Roesch et al., 2007; Tien et al., 1979). This genus presents contributions for several plant characteristics, among them plant height (Braccini et al., 2012), leaf $\mathrm{N}$ content (Nunes et al., 2015; Pereira et al., 2015), shoot dry matter yield (Braccini et al., 2012; Lana et al., 2012; Marini et al., 2015) and grain yield (Ferreira et al., 2013; Hungriaet al., 2010; Lana et al., 2012).

Plant genotype may influence $\mathrm{N}_{2}$ fixation efficiency and/or the ability to promote plant growth, for example corn with Azospirillum (Pereira et al., 2015; Reis Junior et al., 2008). Dartora et al. (2013) observed different behaviors of corn genotypes submitted to the combined inoculation of Azospirillum brasilens and Herbaspirillum seropedicae, providing increments in stem basal diameter, shoot dry matter and grain yield. However, results on the inoculation of grasses have been discrepant, which do not always follow the same trend, being able to raise or reduce a certain variable (Lana et al., 2012; Nunes et al., 2015).

Based on the above, the aim of this work was to evaluate the development of corn genotypes under the effect of inoculation with $A$. brasilense in association with nitrogen fertilization.

\section{MATERIAL AND METHODS}

The experiment was conducted in open field vases at the Department of Agrarian Sciences - Federal University of Paraná (UFPR) from January to May 2013 in Curitiba, PR, located at geographic coordinates $25^{\circ} 24^{\prime} 47^{\prime \prime}$ south latitude and $49^{\circ} 14^{\prime} 58^{\prime \prime}$ west longitude with average altitude of $915 \mathrm{~m}$. It is located in the first Paraná plateau, with Cfb type climate, according to the Köppen classification.

According Marques and Motta (2004), the chemical characteristics of soil collected in the $0-20 \mathrm{~cm}$ depth layer before experiment installation were: $\mathrm{pH}$ in $\mathrm{CaCl}_{2}$ of 5.8; $\mathrm{pH}$ in SMP of 6.1; potential acidity $(\mathrm{H}+\mathrm{Al})$ of $4.6 \mathrm{cmol}_{\mathrm{c}} \mathrm{dm}^{-3} ; 27.4 \mathrm{~g} \mathrm{dm}^{-3}$ of carbon (C); $8.0 \mathrm{cmol}_{\mathrm{c}}$ $\mathrm{dm}^{-3}$ of calcium $\left(\mathrm{Ca}^{2+}\right) ; 4.9 \mathrm{cmol}_{\mathrm{c}} \mathrm{dm}^{-3}$ of magnesium $\left(\mathrm{Mg}^{2+}\right) ; 2.1 \mathrm{cmol}_{\mathrm{cm}} \mathrm{dm}^{-3}$ of potassium $\left(\mathrm{K}^{+}\right) ; 44.3 \mathrm{mg} \mathrm{dm}^{-3}$ of phosphorus (P) (Mehlich 1); $7.37 \mathrm{mg} \mathrm{dm}^{-3}$ of iron $\left(\mathrm{Fe}^{2+}\right) ; 0.11 \mathrm{mg} \mathrm{dm}^{-3}$ of copper $\left(\mathrm{Cu}^{2+}\right) ; 5.02 \mathrm{mg} \mathrm{dm}^{-3}$ of manganese $\left(\mathrm{Mn}^{2+}\right) ; 0.95 \mathrm{mg} \mathrm{dm}^{-3}$ of zinc $\left(\mathrm{Zn}^{2+}\right) ; 15 \mathrm{cmol}_{0}$ $\mathrm{dm}^{-3}$ of base sum; $19.6 \mathrm{cmol}_{\mathrm{c}} \mathrm{dm}^{-3}$ of cation exchange capacity (CEC) and $76.5 \%$ of base saturation ( $\mathrm{V} \%$ ).

The experimental design was completely randomized in a $(5 \times 2 \times 2)$ factorial design with three replicates. The experimental unit consisted of a vase (8 $L)$ containing one plant. Five commercial corn hybrids were used (DKB 566 PRO, BG7060 PRE 32D10, P30F53, FÓRMULA TL) in combination with two $\mathrm{N}$ doses (without and with application of $100 \mathrm{~kg} \mathrm{ha}^{-1}$ of N) and with two levels of $A$. brasilense inoculation (without and with inoculation).

Corn seeds were inoculated with $A$. brasilense through a commercial peaty solid inoculant containing AbV5 and AbV6 (bacteria) strains with $2 \times 10^{8} \mathrm{CFUg}^{-1}$ in the ratio of $200 \mathrm{~g}$ of inoculant to $25 \mathrm{~kg}$ of seed. A $10 \%$ sugar solution in the ratio of $300 \mathrm{ml}$ to $50 \mathrm{~kg}$ of seeds was used to increase peat adhesion on the seed surface (Hungria et al., 2010). Inoculation was carried out by adding the sucrose solution through an automatic pipette on seeds, followed by the inoculant and, with subsequent mixing in seeds prior to sowing.

All treatments received of $P\left(160 \mathrm{mg} \mathrm{kg}^{-1}\right)$ and $\mathrm{K}$ (150 $\mathrm{mg} \mathrm{kg}^{-1}$ ) applications before sowing, incorporated into the vase soil $(6.650 \mathrm{~kg})$, in the forms of single superphosphate (SSP) and potassium chloride $(\mathrm{KCl})$, respectively. The $\mathrm{N}$ source was urea $(46 \%$ of $\mathrm{N})$, incorporated into the soil in two stages, $75 \mathrm{mg} \mathrm{kg}^{-1}$ of $\mathrm{N}$ in V2 and $177 \mathrm{mg} \mathrm{Kg}^{-1}$ of $\mathrm{N}$ in V5, according to preestablished treatments.

Corn sowing was carried out on January, with three seeds per vase at $4 \mathrm{~cm}$ depth. After 27 days of emergence, thinning was performed, leaving one plant per vase. Weed control was manually performed, with no disease control. Parameters plant height, stem diameter at the smaller and larger diameter, leaf chlorophyll content, shoot dry matter yield (SDMY) and shoot nitrogen content were evaluated. Plant height and stem diameter were evaluated at stadiums V8 and R1 by using a measuring tape from the soil surface to the insertion of the flag leaf and a digital pachymeter was 
used to measure the stem diameter in the first internode visible above the soil, respectively.

The determination of the relative chlorophyll content in leaves was carried out with readings in stadium $\mathrm{R} 1$, through $\mathrm{N}$-Tester ${ }^{\circledR}$ (Yara) manual chlorophyllometer. Readings were performed on the first leaf above and opposite to the main corn ear, at points located in the region of the middle third of the leaf (thirty per leaf), from the base and $2 \mathrm{~cm}$ from the two leaf margins. For greater accuracy, the $\mathrm{N}$-Tester@ automatically displays the average value of thirty readings.

The nitrogen content $(\mathrm{N})$ in the index leaf was determined in the middle third of the opposite leaf and below the point of insertion of the main corn ear, collected at the flowering stadium (Argenta et al., 2001). Index leaf samples were placed in greenhouse with forced air circulation for drying at $65 \pm 2{ }^{\circ} \mathrm{C}$ for $72 \mathrm{~h}$ and milled in a Willye knife mill, for $\mathrm{N}$ determination through Kjeldahl digestion followed by distillation and titration as described in Tedesco et al. (1995).

In order to determine the shoot dry matter content, plants were cut in the first visible internode above the soil in the R2 stadium, then they were sectioned and conditioned in paper bags, identified and placed in greenhouse with forced air circulation for drying at $65^{\circ} \mathrm{C} \pm 2{ }^{\circ} \mathrm{C}$ until constant weight for final matter quantification.

Data were submitted to analysis of variance (ANOVA), by SISVAR statistic software (Ferreira, 2014), and in case of significance for corn hybrids, means obtained were compared by the Tukey test at 5 $\%$ significance level.

\section{RESULTS AND DISCUSSION}

In the evaluated characteristics, no interaction between hybrids, nitrogen fertilization and $A$. brasilense inoculation was observed (Table 1), and these results are similar to those observed by Cavallet et al. (2000), when carrying out experiments with commercial product containing Azospirillum spp. Similarly, Dartora et al. (2013) observed no significant interaction between $A$. brasilense inoculation and $H$. seropedicae and nitrogen fertilization for variables plant height, stem basal diameter and shoot dry matter. Perhaps, this was due to competition among soil organisms, considering that the soil used for this experiment was not previously sterilized.

Table 1. Plant height variation (PHV) and stem basal diameter (SD) in the vegetative (V) and reproductive phases (R) and chlorophyll content (ClorF), leaf $\mathrm{N}$ content (LN) and shoot dry matter (SDM) in the reproductive phase of corn plants as a function of genotype, Azospirillum brasilense inoculation and nitrogen doses

\begin{tabular}{|c|c|c|c|c|c|c|c|}
\hline \multirow{2}{*}{ Treatments } & \multicolumn{2}{|c|}{${ }_{-} \mathrm{PHV}(\mathrm{cm})_{-}$} & \multicolumn{2}{|c|}{$\ldots \mathrm{SD}(\mathrm{mm})$} & \multirow[t]{2}{*}{ ClorF } & SDM (g plant ${ }^{-1}$ ) & \multirow{2}{*}{$\mathrm{R}^{\mathrm{LN}\left(\mathrm{g} \mathrm{kg}^{-1}\right)}$} \\
\hline & V & $\mathrm{R}$ & V & $\mathrm{R}$ & & $\mathrm{R}$ & \\
\hline \multicolumn{8}{|l|}{ Genotype } \\
\hline $\mathrm{BG} 7060 \mathrm{H}$ & $41.7 a^{*}$ & $125.4 a b$ & $22.2 \mathrm{a}$ & $20.8 \mathrm{a}$ & $242.7 \mathrm{c}$ & $108.7 a b$ & $16.9 \mathrm{a}$ \\
\hline DKB566 PRO & $44.3 \mathrm{a}$ & $133.3 \mathrm{a}$ & $21.2 a b$ & $19.7 \mathrm{ab}$ & $315.8 \mathrm{ab}$ & $115.0 \mathrm{ab}$ & $10.8 \mathrm{a}$ \\
\hline FÓRMULA TL & $43.8 \mathrm{a}$ & $135.06 \mathrm{a}$ & $21.6 \mathrm{ab}$ & $20.0 a b$ & $334.2 \mathrm{a}$ & $125.8 \mathrm{a}$ & $10.1 \mathrm{a}$ \\
\hline P30F53 & $40.2 \mathrm{a}$ & $114.9 b$ & $20.0 \mathrm{~b}$ & $18.54 \mathrm{~b}$ & $259.0 \mathrm{bc}$ & $97.56 \mathrm{~b}$ & $12.5 \mathrm{a}$ \\
\hline PRE32D10 & $40.0 \mathrm{a}$ & $112.0 \mathrm{~b}$ & $21.0 \mathrm{ab}$ & $19.4 a b$ & $316.5 a b$ & $101.22 b$ & $14.6 \mathrm{a}$ \\
\hline \multicolumn{8}{|c|}{$\mathrm{N}$ in topdressing } \\
\hline \multicolumn{8}{|l|}{$\left(\mathrm{Kg} \mathrm{ha}^{-1}\right)$} \\
\hline 0 & $36.2 \mathrm{~b}$ & $117.5 b$ & $18.7 b$ & $17.3 b$ & $209.8 b$ & $73.1 \mathrm{~b}$ & $9.0 \mathrm{~b}$ \\
\hline 100 & $47.7 \mathrm{a}$ & $130.7 \mathrm{a}$ & $23.6 \mathrm{a}$ & $22.1 \mathrm{a}$ & $377.6 \mathrm{a}$ & $146.2 \mathrm{a}$ & $17.0 \mathrm{a}$ \\
\hline \multicolumn{8}{|l|}{ Inoculation } \\
\hline without & $41.7 \mathrm{a}$ & $123.3 \mathrm{a}$ & $21.3 \mathrm{a}$ & $19.9 \mathrm{a}$ & $302.0 \mathrm{a}$ & $113.3 \mathrm{a}$ & $12.0 \mathrm{a}$ \\
\hline with & $42.3 \mathrm{a}$ & $125.0 \mathrm{a}$ & $20.9 a$ & $19.5 \mathrm{a}$ & $385.3 \mathrm{a}$ & $106.0 \mathrm{a}$ & $13.9 \mathrm{a}$ \\
\hline CV $\%$ & 15.40 & 11.5 & 8.4 & 8.8 & 11.6 & 17.7 & 25.1 \\
\hline
\end{tabular}

*Means followed by the same letter in the column do not differ at $5 \%$ probability level by the Tukey test.

In general, the highest values for the evaluated variables were observed in Formula TL hybrid, while the smallest ones were observed in P30F53 (Table 1). This difference can be attributed to the genetic potential of 
each genotype. Dotto et al. (2010) also found differences in the performance of corn hybrids in an experiment with $\mathrm{H}$. seropedicae inoculation and $\mathrm{N}$ doses.

The leaf nitrogen content did not vary among analyzed hybrids, and all presented lower values compared to reference values $\left(20-24 \mathrm{~g} \mathrm{~kg}^{-1}\right)$ (NEPAR, 2017), unlike that verified by Marini et al. (2015), which obtained differences in nitrogen content using two corn hybrids (30F53; CD383).

Nitrogen application provided increases in plant height, stem diameter, chlorophyll content and foliar nitrogen as observed by Morais et al. (2015) and shoot dry matter yield, similar to that found by Lana et al. (2012). Okumura et al. (2011) verified a positive relationship between nitrogen application and plant height. The positive effect as a function of $\mathrm{N}$ is due to the performance of this nutrient in plant metabolism, used in the synthesis of proteins and chlorophylls (Hawkesford et al., 2012), in addition to the influence in processes such as leaf expansion and photosynthetic rate (Okumura et al., 2011). According to Gomes et al. (2007), leaf nitrogen level has positive correlation with grain production.

Inoculation of corn genotypes with $A$. brasilense AbV5 and AbV6 strains did not modify plant height, stem diameter, dry matter production, as well as the chlorophyll and nitrogen content in leaves of plants in both vegetative and reproductive phase (Table 1). Marini et al. (1999), also observed no variation in plant height, stem diameter and nitrogen content with the inoculation of two corn hybrids with A. brasilense. Pereira et al. (2015) and Morais et al. (2015) observed no effect of this inoculation on chlorophyll and leaf nitrogen contents. In general, the increase in chlorophyll content corresponds to an increase of photosynthesis, which is related to the increase of plant vigor and production (Bashan et al., 2006; Okumura et al., 2011).

The effects on stem basal diameter, chlorophyll content and dry matter production are contrasting, since Dartora et al. (2013) verified increases in stem basal diameter, Lana et al. (2012) and Quadros et al. (2014) observed increase in shoot dry matter yield, chlorophyll content and plant height, when corn was inoculated with A. brasilense. These variations in results obtained with A. brasilense inoculation corroborate Lana et al. (2012), who reported that the same trend of effects does not always occur.
The greatest variations observed were due to nitrogen fertilization and to the hybrid used, pointing that the plant response was not due to the fixation of atmospheric $\mathrm{N}_{2}$ by $A$. brasilense or root growth provided by hormones produced by this bacterium (Pedrinho et al., 2010; Roesch et al., 2007; Tien et al., 1979), but to the higher supply of nitrogen and variation in genotype efficiency in soil nitrogen absorption (Dobbelaere et al., 2002).

It could be concluded that there is variation among corn genotypes regarding development, with Formula TL hybrid presenting the highest chlorophyll content and shoot dry matter values, while $\mathrm{BG} 7060 \mathrm{H}$, stem basal diameter and DKB566 PRO, plant height in the reproductive phase and nitrogen application provided significant increase in corn development and their content on leaves, shoot dry matter and in all other parameters evaluated, while the same was not observed with $A$. brasilense, showing no effect with inoculation.

\section{REFERENCES}

Argenta, G.; Silva, P. R. F.; Bortolini, C. G. Clorofila na folha como indicador do nível de nitrogênio em cereais. Ciência Rural, 2001, 31, 715-722.

Bashan, Y.; Bustillos, J. J.; Leyva, L. A.; Hernandez, J. P.; Bacilio, M. Increase in auxiliary photoprotective photosynthetic pigments in wheat seedlings induced by Azospirillum brasilense. Biology and Fertility of Soils, 2006, 42, 279-285.

Braccini, A. L.; Dan, L. G. M.; Piccinin, G. G.; Albrecht, L. P.; Barbosa, M. C.; Ortiz, A. R. T. Seed inoculation with Azospirillum brasilense, associated with the use of bioregulators in maize. Revista Caatinga, 2012, 25,5864.

Cavallet, L. E.; Pessoa, A. C. S.; Helmich, J. J. Helmich, P. R.; Ost, C. F. Produtividade do milho em resposta à aplicação de nitrogênio e inoculação das sementes com Azospirillum spp. Revista Brasileira de Engenharia Agrícola e Ambiental, 2000, 4,129-132.

Companhia Nacional de Abastecimento (Conab). Acompanhamento da Safra brasileira de grãos, $8^{\circ}$ levantamento. Available from: http://www.conab.gov. br/OlalaCMS/uploads/arquivos/17_05_12_10_37_57_ 
boletim_graos_maio_2017.pdf. Accessed in May 17, 2017.

Dobbelaere, S.; Croonenborghs, A.; Trys, A.; Ptacek, D.; Okon, Y.; Vanderleyden, J. Effect of inoculation with wild type Azospirillum brasilense and $A$. irakenses trains on development and nitrogen uptake of spring wheat and grain maize. Biology and Fertility of Soils. 2002, 36, 284-297.

Dartora, J.; Guimaraes, V.F.; Marini, D.; Sander, G. Adubação nitrogenada associada à inoculação com Azospirillum brasilense e Herbaspirillum seropedicae na cultura do milho. Revista Brasileira de Engenharia Agrícola e Ambiental, 2013, 17, 1023-1029.

Dotto A.P.; Lana, M. C.; Steiner, F.; Frandoloso J.F. Produtividade do milho em resposta à inoculação com Herbaspirillum seropedicae sob diferentes níveis de nitrogênio. Revista Brasileira de Ciências Agrárias, 2010, 5, 376-382.

Dobereiner, J.; Pedrosa, F. O. Nitrogen-fixing bacteria in non leguminous crop plants. Science Tech. Madison, WI: Springer-Verlag, 1987.

FAO. Food and Agriculture Organization. Food and Agricultural commodities production - Commodities by regions. 2013a. Available from: http://faostat3.fao.org/ browse/rankings/commodities_by_regions/E. Accessed in June 18, 2015.

FAO. Food and Agriculture Organization. Food and Agricultural commodities production - Countries by commodity. 2013b. Available from: http://faostat3. fao.org/browse/rankings/countries_by_commodity/E. Accessed in June 18, 2015.

Ferreira, A.S.; Pires, R. R.; Rabelo, P. G.; Oliveira, R. C.; Luz, J.M.Q.; Brito, C.H. Implications of Azospirillum brasilense inoculation and nutrient addition on maize in soils of the Brazilian Cerrado under greenhouse and field conditions. Applied Soil Ecology, 2013, 72, 103108.

Ferreira, D.F. Sisvar: a Guide for its Bootstrap procedures in multiple comparisons. Ciência e Agrotecnologia, 2014, 38, 109-112
Fontoura, S.M.V. Adubação nitrogenada na cultura do milho em Entre Rios, Guarapuava, Paraná. Fundação Agrária de Pesquisa Agropecuária, Guarapuava, Paraná, 2005.

Gomes, R. F., Silva, A. G., Assis, R. L.; Pires, F. R. Efeito de doses e da época de aplicação de nitrogênio nos caracteres agronômicos da cultura do milho sob plantio direto. Revista Brasileira de Ciência do Solo, 2007, 31, 931-938.

Halvorson, A. D.; Peterson, G. A.; Reule, C. A. Tillage system and crop rotation effects on dry land crop yields and soil carbon in the Central Great Plains. Agronomy Journal, 2002, 94,1429-1436.

Hawkesford, M.; Horst, W.; Kichey, T.; Lambers, H.; Schjoerring, J.; Skrumsager Moller, I.; White, P. Functions of macronutrients. In: Mineral nutrition of higher plants, Marschner P, Ed; Elsevier Ltd.:San Diego, CA, 2012; pp. 135-189.

Hungria, M.; Campo, R.; Souza, E.; Pedrosa, F. Inoculation with selected strains of Azospirilum brasilense and $A$. lipoferum improves yields of maize and wheat in Brazil. Plant and Soil, 2010, 331, 413-425.

Lana, M. C.; Dartora, J.; Marini, D.; Hann, J. E. Inoculation with Azospirillum, associated with nitrogen fertilization in maize. Revista Ceres, 2012, 59, 399-405.

Ladha, J.K.; Pathak, H.; Krupnik, T.J.; Six, J.; Kessel, C.V. Efficiency of fertilizer nitrogen in cereal production: retrospects and prospects. Advances in Agronomy, 2005, 87, 84-156.

Marini, D.; Guimarães, V.F.; Dartora, J.; Lana, M. C.; PintoJúnior, A. S. Growth and yield of corn hybrids in response to association with Azospirillum brasilense and nitrogen fertilization. Revista Ceres, 2015, 62,117123.

Marques R.; Motta, A. C. V. Análise química do solo para fins de fertilidade. In: Lima M. R., editor. Manual de diagnóstico de fertilidade e manejo dos solos agrícolas. 2nd ed. Curitiba: Imprensa Universitária da UFPR: Curitiba, PR, 2003; pp. 82-102.

Morais, T. P.; Brito, C. H.; Ferreira, A. S.; Luiz, J. M. 
Q. Aspectos morfofisiológicos de plantas de milho e bioquímico do solo em respostaà adubação nitrogenada e à inoculação com Azospirillum brasilense. Revista Ceres, 2015, 62, 589-596.

NEPAR - Núcleo Estadual do Paraná - Sociedade Brasileira de Ciência do Solo. Manual de adubação e calagem para o Estado do Paraná. SBCS/NEPAR: Curitiba, PR, 2017; 482 p.

Nunes, P. H. M. P.; Aquino, L. A.; Santos, L. P. D.; Dezordi, L. R.; Assunção, N. S. Produtividade do trigo irrigado submetido à aplicação de nitrogênio e à inoculação com Azospirillum brasilense. Revista Brasileira de Ciência do Solo, 2015, 39, 174-182.

NogaraNeto, F.; Roloff, G.; Dieckow, J.; Motta, A. C. V. Atributos de solo e cultura espacialmente distribuídos relacionados ao rendimento do milho. Revista Brasileira de Ciência do Solo, 2011, 35, 1025-1036.

Okumura, R. S.; Takahashi, H. W.; Santos, D. G. C.; Lobato, A. K. S.; Mariano, D. C.; Marques, O. J.; Silva, M. H. L.; Oliveira Neto, C. F.; Lima Junior, J. A. Influence of different nitrogen levels on growth and production parameters in maize plants. Journal of Food, Agriculture \& Environment, 2011, 9, 510-514.

Pedrinho, E. A. N.; Galdiano Júnior, R. F.; Campanharo, J. C.; Alves, M. C.; Lemos, E. G. M. Identificação e avaliação de rizobactérias isoladas de raízes de milho. Bragantia, 2010, 69, 905-911.

Pereira, L. M.; Pereira, E. M.; Revolti, L. T. M.; Zingaretti, S. M.; Môro, G. V. Seed quality, chlorophyll content index and leaf nitrogen levels in maize inoculated with Azospirillum brasilense. Revista Ciência Agronômica, 2015, 46, 630-637.
Quadros, P. D.; Roesc, L. F. W.; Silva, P. R. F.; Vieiras, V. M.; Roehrs, D. D.; Camargo, F. A. O. Desempenho agronômico a campo de híbridos de milho inoculados com Azospirillum. Revista Ceres, 2014, 61, 209-218.

Radwan, T. E. E.; Mohamed Z. K.; Reis V. M. Efeito da inoculação de Azospirillum e Herbaspirillum na produção de compostos indólicos em plântulas de milho e arroz. Pesquisa Agropecuária Brasileira, 2004, $39,987-994$

Reis Junior, F. B.; Machado, C. T.T.; Machado, A. T.; Sodek, L. Inoculação de Azospirillum amazonense em dois genótipos de milho sob diferentes regimes de nitrogênio. Revista Brasileira de Ciência do Solo, 2008, $32,1139-1146$

Roesch, L. F. W.; Quadros, P. D.; Camargo, F. A. O.; Triplett, E. W. Screening of diazotrophic bacteria Azopirillum spp. for nitrogen fixation and auxin production in multiple field sites in southern Brazil. World Journal of Microbiology Biotechnology, 2007, 23, 1377-1383.

Tedesco, M. J.; Gianello, C.; Bissani, C. A.; Bohnen, H.; Volkweiss, S. J. Análises de solo, plantas e outros materiais. Departamento de solos-UFRGS, Porto Alegre, Rio Grande do Sul, 1995.

Tien, T. M.; Gaskins, M. H.; Hubbell, D. H. Plant growth substances produced by Azospirillum brasilense and their effect on the growth of pearl millet (Pennisetum americanum L.). Applied Environmental Microbiology, 1979, 37, 1016-102. 